\title{
Histological and biochemical serum effects of alpha-tocopherol on ischemia/ reperfusion-related injuries induced in the pelvic limb of rats ${ }^{1}$
}

\author{
Efeitos histológicos e bioquímicos séricos do alfa-tocoferol na lesão de isquemia e \\ reperfusão em membro pélvico de ratos
}

\author{
Marcelo Gomes da Silva², Aldemar Araújo Castro ${ }^{3}$, Eduardo Antonio Gonçalves Ramos ${ }^{4}$, Ediriomar Peixoto ${ }^{5}$, \\ Fausto Miranda Jr ${ }^{6}$, Guilherme de Benjamin Brandão Pitta ${ }^{7}$, Regina de Faria Bittencourt Costa ${ }^{8}$, Yara Juliano ${ }^{9}$ \\ 1. Master's Thesis presented to the Federal University of Sao Paulo, Paulista Medical School (UNIFESP-EPM) - Work performed at Escola \\ Bahiana de Medicina (Bahiana School of Medicine). \\ 2. Postgraduate Fellow from UNIFESP-EPM; Vascular Surgeon, Professor of Anatomy, Faculty of Technology and Science, Salvador, BA \\ (Brazil). \\ 3. Assistant Professor of Methodology of Scientific Research, University of Sciences of Alagoas (AL, Brazil). \\ 4. Associate Professor, Pathologist, Federal University of Bahia; Chief of the Histopathology Unit, Oswaldo Cruz Foundation - FIOCRUZ, \\ Salvador, BA (Brazil). \\ 5. Full Professor, Department of Experimental Surgery and Operative Technique, Bahiana School of Medicine and Public Health, Salvador, \\ BA (Brazil). \\ 6. Full Professor; Chief, Discipline of Vascular Surgery, Department of Surgery, UNIFESP-EPM, Sao Paulo, SP (Brazil). \\ 7. PhD, Associate Professor, Department of Surgery, Governor Lamenha Filho University Foundation for Science and Health of Alagoas, \\ Maceio, AL (Brazil). \\ 8. PhD Degree from UNIFESP-EPM; Chief, Vascular Surgery Service, Heliopolis Hospital, Sao Paulo, SP (Brazil). \\ 9. Associate Professor, Discipline of Biostatistics, Department of Preventive Medicine, UNIFESP-EPM, Sao Paulo, SP (Brazil).
}

\begin{abstract}
Purpose: To evaluate the protective action of alpha-tocopherol in ischemia/reperfusion injuries of pelvic member of rats. Methods: Thirty adult male rats of the Wistar strain were randomized into three experimental groups of 10: Group I - control group with no ischemia or reperfusion. Groups II and III - four hours of ischemia and of hours of reperfusion by means of clamping of the infrarenal aorta. The animals of Group II were treated with saline and those of Group III were treated with i.v. alpha-tocopherol (50 mg $/ \mathrm{kg}$ ). Parameters studied were biopsies of the soleus muscle, dosing of creatine phosphokinase, lactate dehydrogenase, potassium, calcium and arterial blood gasometry. Results: The results of biopsies of the soleus muscles studied by optical microscopy, were not significant in terms of presence of edema among the three groups studied. Variables inflammation and necrosis were not observed, therefore cannot be statistically analyzed. As to dosing of calcium and lactate dehydrogenase, the ${ }_{p} \mathrm{H}, \mathrm{O}_{2}$ and ${ }_{p} \mathrm{CO}_{2}$ values were not significant for all groups studied. We observed that the levels of potassium (Group II $>$ Group I, $\mathrm{F}_{\text {calculated }}=5.84 ; \mathrm{F}_{\text {critical }}=3.33$ ), creatine phosphokinase (Group II $>$ Groups I and III, $\mathrm{H}_{\text {calculated }}=13.92 ; \mathrm{H}_{\text {critical }}=5.99$ ) and bicarbonate (Groups I and III $>$ Group II, $\mathrm{H}_{\text {calculated }}=11.98 ; \mathrm{H}_{\text {critical }}=$ 5.99) presented significant results among groups. Conclusion: From the serum biochemical perspective, the treatment with alpha-tocopherol has attenuated the metabolic injuries in the ischemia/reperfusion syndrome in this experimental model. Key words: Ischemia. Reperfusion. alpha-Tocopherol. Rats.
\end{abstract}

\section{RESUMO}

Objetivo: Avaliar ação protetora do alfa-tocoferol na lesão de isquemia e reperfusão em membro pélvico de ratos. Métodos: Trinta ratos machos adultos da linhagem wistar foram distribuídos aleatoriamente, em três grupos experimentais, com 10 animais cada: Grupo I - Grupo controle sem isquemia ou reperfusão. Grupos II e III - quatro horas de isquemia e duas horas de reperfusão através clampeamento da aorta infra-renal. Os animais do grupo II foram tratados com solução salina e aqueles do grupo III, tratados com alfa-tocoferol $50 \mathrm{mg} / \mathrm{kg}$ por via endovenosa. Parâmetros estudados: Biópsias do músculo solear, dosagens da creatina fosfoquinase, da desidrogenasse láctica, do potássio, do cálcio e da hemogasometria arterial. Resultados: Os resultados das biópsias dos músculos soleares estudados através da microscopia óptica, não foram significantes quanto a presença de edema entre os três grupos estudados. As variáveis inflamação e necrose não foram observadas e, portanto não analisáveis estatisticamente. Em relação às dosagens de cálcio e desidrogenase lática, ${ }_{\mathrm{p}} \mathrm{H}, \mathrm{O}_{2},{ }_{\mathrm{p}} \mathrm{CO}_{2}$, não foram significantes em todos os grupos estudados. Observamos que os níveis de potássio (Grupo II > grupo I, F calculado = 5,84; F crítico = 3,33), creatina fosfoquinase (Grupo II > Grupo I e III, H calculado =13,92; Hcritico 5,99 ) , e bicarbonato (grupo I e III > grupo II, H calculado = 11,98; h critico 5.99 ) apresentaram resultados significantes entre os grupos. Conclusão: Tratamento com alfa-tocoferol do ponto de vista bioquímico sérico atenuou as lesões metabólicas na síndrome de isquemia e reperfusão neste modelo experimental.

Descritores: Isquemia.Reperfusão.alfa-Tocoferol.Ratos. 


\section{Introduction}

Ischemia caused by oxygen deficit plays an important role in the pathophysiology of many medical-surgical conditions such as myocardial infarction, hypovolemic shock, bowel obstructions and peripheral vascular disease. Although the restoration of blood flow to an ischemic organ is essential to prevent irreversible cell damage, reperfusion may aggravate the ischemic cell damage, as shown by experimental models with temporary occlusions and reperfusions in coronary arteries ${ }^{1}$. In order to protect patients against ischemia/reperfusion (I/R) injuries, different types of protection have been suggested and used, such a hypothermia, ischemic preconditioning and induction of successive ischemia/reperfusion by intermittent clamping for different periods, as well as drug use before, during and after the onset of ischemia ${ }^{2}$. Experimental trials have shown the efficacy of drugs to prevent or attenuate ischemia/ reperfusion injuries. Superoxide dismutase, catalase, mannitol, hypertonic solutions, allopurinol, Nacetylcysteine, iron binding compounds, angiotensinconverting enzyme inhibitors, calcium channel antagonists, and alpha-tocopherol have been tested ${ }^{3-6}$. Alpha-tocopherol is the major component of vitamin $\mathrm{E}$, a group of substances with similar structures. Alpha-tocopherol is considered the most effective liposoluble antioxidant found in the human biological system. As it interacts with free radicals, the chain reaction of these radicals starts, preventing lipid peroxidation, a process that generates products that are harmful to cells ${ }^{7}$. Experimental studies have shown that the use of alpha-tocopherol after ischemia/reperfusion in animals not only attenuated the oxidative injury of the muscle cells but also reduced the formation of edema in these cells, which means that they have a partial protective action ${ }^{8}$. Thus, considering the importance of acute arterial occlusion and its serious systemic consequences, for instance, the need for occlusion of the infrarenal abdominal aorta in medical-surgical conditions such as the correction of aneurisms, and trauma, an ischemia/reperfusion experimental study was performed in rats subjected to temporary clamping of the infrarenal abdominal aorta, with the purpose of evaluating the following:

- Biochemical changes secondary to muscle ischemia/reperfusion.

- Histological findings present in skeletal muscles.

\section{Methods}

\section{Sample}

Thirty male adult Rattus norvegicus albinus of the Wistar-OUTB strain provided by the Department of Experimental Surgery and Operative Technique, Bahiana School of Medicine and Public Health, aged between 90 and 120 days, with body weight between 295 and 350 grams. All rats were handled according to the Ethical Principles for Animal Experiments of the International Council for Animal Protection, and Law no. 663 of May 8, 1979. The research project was approved by the Research Ethics Committee of Alagoas University of Science as per research protocol no. $15 \mathrm{~A}$.

\section{Anesthesia}

The animals were weighed and anesthetized using an intraperitoneal injection of ketamine hydrochloride and 2\% aqueous solution of xylazine hydrochloride (5:2) at $60 \mathrm{mg} /$ $\mathrm{kg}$ and $20 \mathrm{mg} / \mathrm{kg}$ body weight, respectively.

\section{Surgery}

Surgeries were performed at the Laboratory of Experimental Surgery and Operative Technique, Bahiana School of Medicine and Public Health. The animals were placed on a board, in horizontal dorsal decubitus, with their pelvic and thoracic members immobilized with adhesive tape. The external jugular vein was isolated and catheterized (using a BD Insyte ${ }^{\circledR}$ catheter 24 ga) for the administration of alpha-tocopherol and saline. All animals were subjected to median laparotomy, the abdominal aorta being exposed and repaired at $1 \mathrm{~cm}$ cranially to its bifurcation using 5.0 monofilament nylon sutures and placing a vascular MicroClampÔ. In this procedure a D.F. VASCONCELOS ${ }^{\circledR}$ surgical microscope with up to 40x magnification was used (Figure 1). The clamping efficacy was proven by flow/reflow maneuvers and repair with monofilament suture in the abdominal aorta, pallor and/or cyanosis of the pelvic members and absence of visible pulses of the iliac arteries under the microscope.

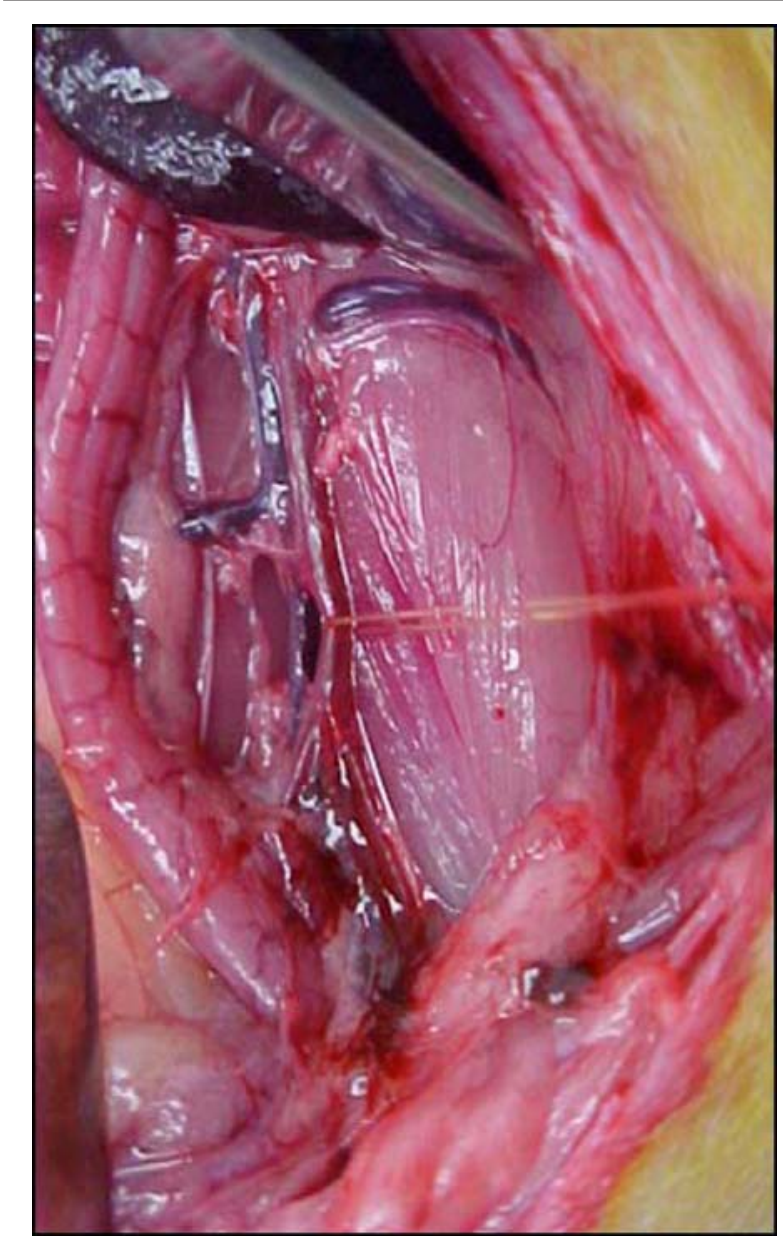

FIGURE 1 - Photo of dissection and isolation of the abdominal aorta. 


\section{Study protocol}

\section{Study groups}

The rats were weighed and randomized immediately prior to the surgery into three groups of 10 animals, using sealed envelopes with the name of the group in question.

Group I (10 animals) - Control group with no ischemia/ reperfusion. The animals were subjected to all operative procedures, except arterial occlusion and reperfusion. After median laparotomy, exposure and isolation of the abdominal aorta for 4 hours, the animals received $2 \mathrm{ml}$ of $0.9 \%$ saline via the external jugular vein and were kept under anesthesia for another 2 hours.

Group II (10 animals) - The animals were subjected to 4 hours of ischemia followed by 2 hours of reperfusion. Two $\mathrm{ml}$ of $0.9 \%$ saline were administered immediately prior to reperfusion.

Group III (10 animals) - Four hours of ischemia followed by 2 hours of reperfusion. A solution of $50 \mathrm{mg} / \mathrm{kg}$ alpha-tocopherol in $0.9 \%$ saline solution was administered, with a total volume of $2 \mathrm{ml}$.

\section{Specimen collection}

At the end of the trial, arterial blood samples were collected by catheterization of the aorta artery by direct punctioning with a BD Insyte ${ }^{\circledR}$ catheter 24 ga for serum studies and biopsy of the soleus muscle, accomplished by incision in the posterior face of the leg, the soleus muscle being sectioned in its insertions to be submitted to histological cuts (Figure 2). Euthanasia was performed using a lethal dose of ketamine hydrochloride + xylazine hydrochloride intravenously.

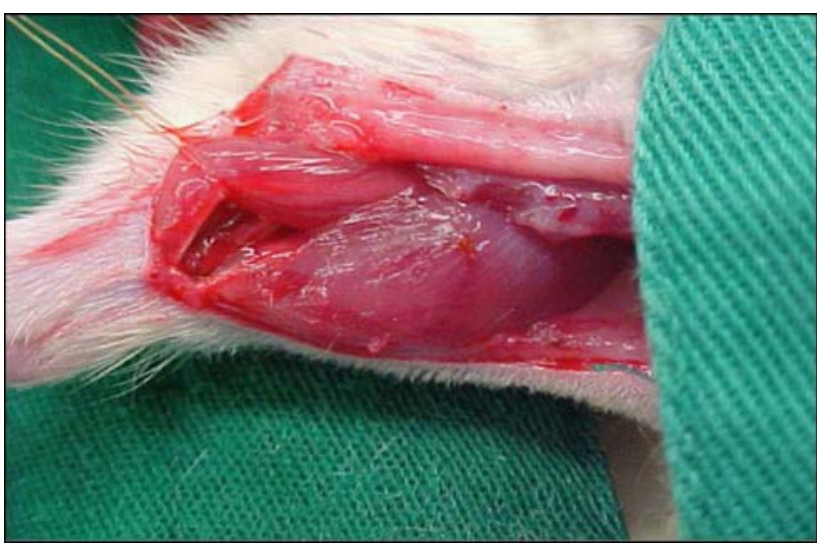

FIGURE 2 - Photo of dissection and isolation of the rat soleus muscle.

\section{Variables studied}

All procedures of laboratory dosing and anatomic pathologic analyses were performed using the blind system concerning the groups, serum samples and histological samples to be studied.

\section{Histological study}

The histological tests of the soleus muscle were performed at the Department of Pathological Anatomy, Oswaldo Cruz Foundation - FIOCRUZ, Salvador, BA(Brazil). The histologic sections were paraffin-embedded. Five $\mu \mathrm{m}$ thick cuts were produced from each piece. The sections were stained using the hematoxylin-eosin (H-E), periodic acid Schiff (PAS) reaction, Picrosirius, and Masson trichromic staining (for collagen fibers) and examined by conventional optical microscopy using a ZEISS ${ }^{\circledR}$ microscope. The histological study consisted of a qualitative analysis to observe the presence or absence of inflammation, edema and necrosis in the soleus muscle studied.

\section{Serum biochemical dosing}

For the serum biochemical evaluation the following values were determined:

Lactate dehydrogenase (LDH), creatine phosphokinase (CPK), potassium, calcium, arterial blood gasometry ${ }_{\mathrm{p}} \mathrm{O}_{2}$, ${ }_{\mathrm{p}} \mathrm{CO}_{2},{ }_{\mathrm{p}} \mathrm{H}$ and bicarbonate).

\section{Statistical methods}

To analyze the results, the following parametric and non-parametric tests were used taking into considerations the variables studied.

1. The Kruskal Wallis test (ANOVA) to compare the three study groups concerning the variables studied ${ }^{10-11}$.

2. The chi-square test to compare the three study groups concerning the frequency of the characteristics studied ${ }^{11}$.

The level of rejection of the null hypothesis was established as 0.05 or $5 \%$ and an asterisk indicates the significant values.

\section{Results}

A significant increase was observed in the levels of potassium $(\mathrm{F}=5.84)$ and $\mathrm{CPK}(\mathrm{f}=13.92)$ in Group II compared to Group I (control) and Group III (a-tocopherol) (Tables 1 and 2). Bicarbonate levels presented the highest elevation in Groups I and III, as compared to Group II (Group I and Group III > Group II). $\mathrm{H}_{\text {calculated }}=11.98$ with $\mathrm{H}_{\text {critical }}=5.99$; a value that is statistically significant (Table 4).

Variables ${ }_{\mathrm{p}} \mathrm{O}_{2},{ }_{\mathrm{p}} \mathrm{H}$ and ${ }_{\mathrm{p}} \mathrm{CO}_{2}$ were similar in the three groups studied, with no statistical significance $\left(\mathrm{H}_{\text {calculated }}\right.$ equal to 2.90, 0.06, 1.23 and 5.01 respectively). Calcium and LDH variables also did not show significant results (Tables 1 to 5 ).

Concerning the histological variables studied, we did not observe the presence of inflammation and necrosis in muscle fibers in the three groups studied. Higher incidence of edema was observed in Group II as compared with Groups I and III, although with no statistical significance $\left(\mathrm{x}^{2}\right.$ calculated $=1.87$ and $\mathrm{x}_{\text {critical }}^{2}=5.99$ ). (Figure 3). 
TABLE 1 - Rats in Group I (Control), Group II (4-hourischemia +2 -h reperfusion with $0.9 \%$ saline) and Group III (4-hour-ischemia + 2-h reperfusion with $\alpha$-tocopherol), according to the calcium and potassium values

\begin{tabular}{llllllll}
\hline & \multicolumn{3}{c}{ CALCIUM } & & \multicolumn{3}{c}{ POTASSIUM } \\
\cline { 2 - 3 } \cline { 6 - 8 } & I & II & III & & I & II & III \\
\hline Mean value & 10.4 & 9.3 & 10.1 & & 5.9 & 6.9 & 6.3 \\
SD & 0.6 & 1.5 & 1.0 & & 0.8 & 0.8 & 0.5 \\
SD: Standard deviation & & & & & \\
\hline
\end{tabular}

\begin{tabular}{|c|c|}
\hline \multicolumn{2}{|c|}{$\begin{array}{c}\text { Variance Analysis } \\
\text { (Group I x Group II x Group III) } \\
\text { Fcritical = } 3.33\end{array}$} \\
\hline CALCIUM & POTASSIUM \\
\hline $\mathrm{F}_{\text {calculated }}=2.90$ & $\mathrm{~F}_{\text {calculated }}=5.84^{*}$ \\
\hline
\end{tabular}

TABLE 2 - Rats in Group I (Control), Group II (4-hourischemia +2 -h reperfusion with $0.9 \%$ saline) and Group III (4-hour-ischemia + 2-h reperfusion with $\alpha$-tocopherol), according to $\mathrm{LDH}$ and CPK values

\begin{tabular}{lccccccc}
\hline & \multicolumn{3}{c}{ LDH } & & \multicolumn{3}{c}{ CPK } \\
\cline { 2 - 3 } \cline { 6 - 8 } & I & II & III & & I & II & III \\
\hline Mean value & 2874 & 3021 & 4151 & & 4015 & 8958 & 4686 \\
Median value & 2575 & 2974 & 3927 & & 3551 & 9176 & 3973 \\
Standard & 1571 & 1643 & 1410 & & 1384 & 2976 & 2582 \\
deviation & & & & & & \\
\hline
\end{tabular}

Kruskal-Wallis One-way Analysis of Variance by Ranks (Group I x Group II x Group III)

$$
\mathrm{H}_{\text {critical }}=5.99
$$

$\frac{\text { DHL }}{\mathrm{H}_{\text {calculated }}=3.80} \quad \frac{\text { CPK }}{\mathrm{H}_{\text {calculated }}=13.92^{*}}$

Group II > Groups I and III

TABLE 3 - Rats of Group I (Control), Group II (4 hours of ischemia and 2 hours of reperfusion with $0.9 \%$ saline) and Group III (4 hours of ischemia and 2 hours of reperfusion with alpha-tocopherol), according to the $\mathrm{pH}$ and $\mathrm{pO} 2$ values.

\begin{tabular}{lccccccc}
\hline & \multicolumn{3}{c}{$\mathbf{H}$} & & \multicolumn{3}{c}{$\mathbf{~}_{\mathbf{p}}$} \\
\cline { 2 - 4 } \cline { 7 - 8 } & $\mathbf{I}$ & $\mathbf{I I}$ & $\mathbf{I I I}$ & & $\mathbf{I}$ & $\mathbf{I I}$ & $\mathbf{I I I}$ \\
\hline Mean value & 7.15 & 7.12 & 7.13 & & 153 & 152 & 156 \\
Median value & 7.13 & 7.11 & 7.12 & & 156 & 145 & 153 \\
Standard & 0.04 & 0.08 & 0.03 & & 42 & 42 & 36 \\
deviation & & & & & & \\
\hline
\end{tabular}

Kruskal-Wallis One-way Analysis of Variance by Ranks (Group I x Group II x Group III)

$$
\mathrm{H}_{\text {critical }}=5.99
$$

$$
\frac{{ }_{\mathbf{p}}^{\mathbf{H}}}{\mathrm{H}_{\text {calculated }}=1.23} \quad \frac{{ }_{\mathbf{p}} \mathbf{O}_{2}}{\mathrm{H}_{\text {calculated }}=0.06}
$$

TABLE 4 - Rats of Group I (Control), Group II (4 hours of ischemia 2 hours of reperfusion with $0.9 \%$ saline) and Group III (4 hours of ischemia and 2 hours of reperfusion with alpha-tocopherol), according to the pCO2 and bicarbonate values.

\begin{tabular}{lllllllll}
\hline & \multicolumn{3}{c}{$\mathbf{C O}_{\mathbf{2}}$} & & & \multicolumn{3}{c}{ BICARBONATE } \\
\cline { 2 - 4 } \cline { 7 - 9 } \cline { 7 - 9 } & I & II & III & & I & II & III \\
\hline Mean value & 58 & 42 & 53 & & 19 & 12 & 17 \\
Median value & 62 & 47 & 50 & & 19 & 12 & 16 \\
Standard & 10 & 16 & 9 & & 2 & 5 & 2 \\
deviation & & & & & & & \\
\hline
\end{tabular}

Kruskal-Wallis One-way Analysis of Variance by Ranks (Group I x Group II x Group III)

$$
\frac{{ }_{\mathbf{p}} \mathbf{C O}_{2} \mathrm{H}_{\text {critical }}=5.99}{\mathrm{H}_{\text {calculated }}=5.01} \quad \frac{\text { BICARBONATE }}{\mathrm{H}_{\text {calculated }}=11.98^{*}}
$$

TABLE 5 - Rats of Group I (Control), Group II (4 hours of ischemia and 2 hours of reperfusion with $0.9 \%$ SALINE) and Group III (4 hours of ischemia and 2 hours of reperfusion with alpha-tocopherol), according to the positiveness of the edema, necrosis and inflammation.

\begin{tabular}{ccccc}
\hline \multirow{2}{*}{ Group } & \multicolumn{2}{c}{ EDEMA } & Total & $\begin{array}{c}\% \\
\text { positiveness }\end{array}$ \\
\cline { 2 - 3 } & + & - & & 10 \\
\hline I & 5 & 5 & & 50.0 \\
II & 7 & 3 & 10 & 70.0 \\
III & 4 & 6 & 10 & 40.0 \\
\hline Total & 16 & 14 & 30 & 53.3 \\
\hline
\end{tabular}

Chi square test

$$
\chi_{\text {calculated }}^{2}=1.87 \quad \chi_{\text {critical }}^{2}=5.99
$$




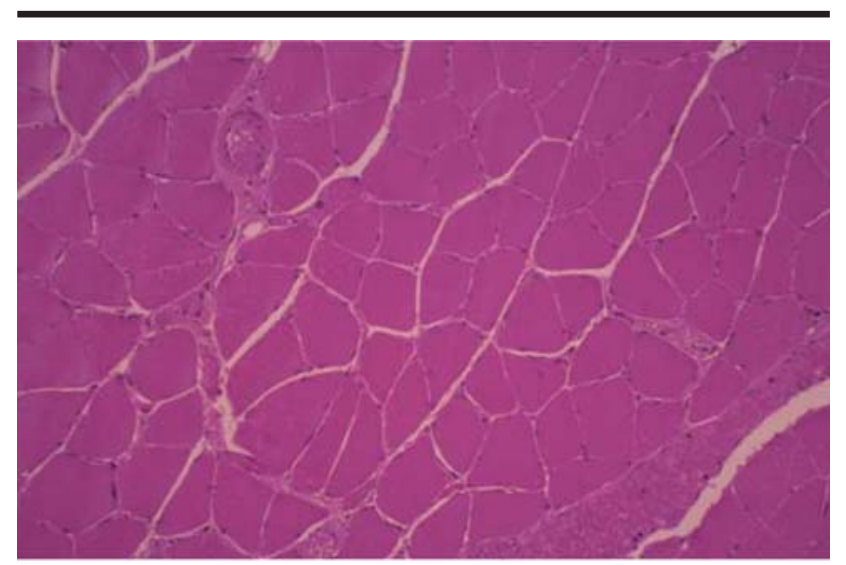

A

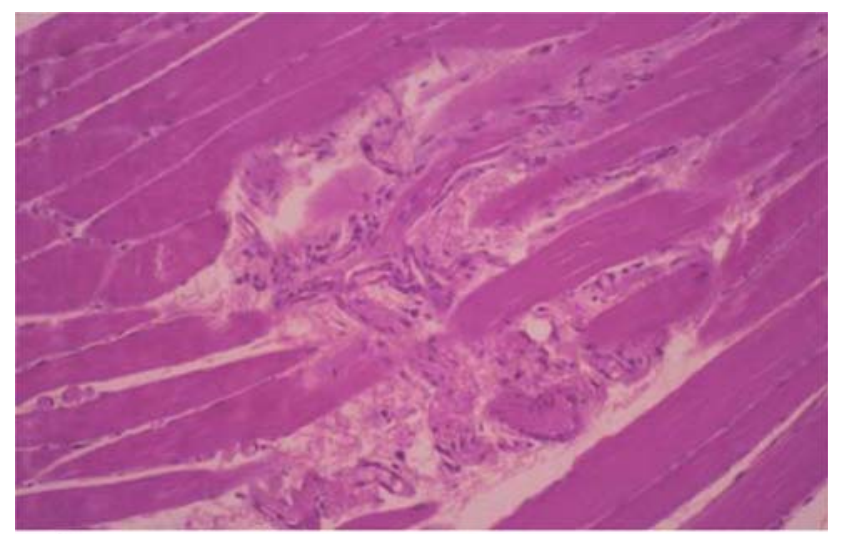

B

FIGURE 3 - Photomicrographs of the analysis of normal striate skeletal soleus muscle (3A). Presence of edema between muscle fibers (3B).

\section{Discussion}

Although it is recognized that prolonged ischemia may cause injury in tissues and organs, the concept of tissue injury after reperfusion defined as tissue injury caused by direct consequence of revascularization is relatively recent. These situations can increase the morbidity and mortality of patients subjected to vascular reconstruction, trauma or transplant. The experimental trial was performed by clamping the terminal abdominal aorta. It is worth noting that we did not apply a ligature to the branches of the aorta, such as the lumbar arteries, the middle sacral artery and the inferior mesenteric artery. Also, we know that the vascularization of the hind leg of the rat presents an exuberant presence of collateral circulation at the level of the external iliac artery and the common femoral artery. These facts should be taken into account during the analysis of the changes found at skeletal muscle level as regards serum biochemical and histological changes ${ }^{12}$.

In this study we used alpha-tocopherol, an extensively studied and one of the most effective antioxidant substances present in biological systems. Its action prevents the oxidation of essential cell components and the formation of toxic products resulting from peroxidation of polyunsaturated fatty acids and known as oxygen free radicals that are produced under adverse conditions such as periods of tissue ischemia ${ }^{2,8}$.
In the past few years, special attention has been given to damage caused by formation of oxygen free radicals, both in the periods of ischemia and later, during reperfusion. It has been evidenced that the origin of free radicals starts with the conversion of xanthine dehydrogenase into xanthine oxidase. The increase of concentration of xanthine oxidase in the tissues is responsible for its increased activity and consequent production of free radicals that will react with the polyunsaturated fatty acids present in the cell membrane, causing their peroxidation, followed by the peroxidation of the cell components. This reaction has been implied in the pathogenesis of the ischemic injuries of different organs and muscle tissues ${ }^{2,8,19}$. The administration route and the dose of alpha-tocopherol were based on published studies that evaluated its efficacy in rats as an antioxidant in situations of acute tissue ischemia ${ }^{6,8,9}$.

The biochemical parameters used were the serum dosing of creatine phosphokinase, lactate dehydrogenase, calcium, potassium, and arterial blood gasometry $\left({ }_{\mathrm{p}} \mathrm{O}_{2},{ }_{\mathrm{P}} \mathrm{CO}_{2}\right.$, ${ }_{\mathrm{p}} \mathrm{H}$ and bicarbonate), as well as histological parameters, by studying the soleus muscle using optical microscopy, where it is possible to observe the level of injury caused in each animal and make intergroup comparisons.

There is no consensus in the literature regarding the dosing of enzymes, something that was shown in an experimental model in rats with 4 hours of ischemia and 1 hour of reperfusion with alpha-tocopherol, where no statistical differences were observed in the dosing of potassium among the groups studied ${ }^{6}$. As we evaluated the dosing of ${ }_{p} \mathrm{H},{ }_{\mathrm{P}} \mathrm{O}_{2}$ and ${ }_{\mathrm{P}} \mathrm{CO}_{2}$ in this study, no statistical difference was observed among groups. Similar results were found when we analyzed these variables in the animals studied $^{6}$. The CPK levels observed were significant and constituted an indirect reflex of cell injury of the member subjected to ischemia/reperfusion in experimental models of rats that used alpha-tocopherol ${ }^{9}$. Similar results were found by a different author ${ }^{6}$.

Experimental study in rats, to evaluate serum dosing after 6 hours of ischemia and 24 hours of reperfusion by clamping the distal aorta in rats, using anti-ICAM-1 antibody before the reperfusion; they are not significant regarding the dosing of potassium and $\mathrm{CPK}$ and the ${ }_{\mathrm{p}} \mathrm{H}$ in the 3 groups studied $^{13}$. In this study we found that the results were significant as compared with the dosing of potassium, CPK and bicarbonate in the control group (Group I) and in the group receiving alpha-tocopherol (Group III) as compared with the group receiving saline solution (Group II). However, in relation to the analyses of lactate dehydrogenase and calcium, the results were similar to those obtained by the above-mentioned authors, and were not significant.

Several authors observed that the edema in the muscle cells was attenuated by different free radical removers such as superoxide dismutase, catalase, mannitol, deferoxamine, allopurinol, alpha-tocopherol, and calcium channel-blocking drugs $4,6,14,15,16$. The analysis of the soleus muscle by optical microscopy revealed the presence of edema of cell muscles in the 3 groups, its incidence being slightly higher in the group receiving saline solution when compared to the control group and the group receiving the alpha-tocopherol solution; this shows that alpha-tocopherol tends to attenuate these injuries, but this trend has no statistical 
significance. An experimental study comparing doses of malondialdehyde (MDA, a product of lipid peroxidation) in blood and skeletal muscle showed that ischemia/reperfusion in rats, using alpha-tocopherol, causes less higher levels in animals treated with alpha-tocopherol before the reperfusion ${ }^{6}$. An experimental study that analyzed changes resulting from ischemia/reperfusion in rats by optical microscopy of kidney, lung and skeletal muscle and the dosing of myeloperoxidase activity using histochemical methods observed that such dosing were more sensible than optical microscopy in terms of metabolic and histological changes ${ }^{13}$.

Renal lesion was shown in one ischemia/reperfusion study to be prevented by alpha-tocopherol in a rat model using electron microscopy ${ }^{17}$. It is worth noting that a review of the literature shows that the most reliable methods to study ischemia/reperfusion injuries include electron microscopy and/or histochemical analyses such as MDA dosing, something that has been shown in experimental trials ${ }^{6,9,10,17,18}$ that quantified histochemically skeletal muscle injuries following ischemia/reperfusion. These methods were not used in this study for lack of availability.

The purpose of reperfusion is to prevent amputation and make it possible for the limb to return to its normal function, besides reducing the systemic effects of the procedure. It is difficult to delimit the boundary between ischemia and reperfusion. What we do observe is a relationship of dependence and fortuity between them, since apparently the intensity of injuries attributed to reperfusion is proportional to the duration of ischemia. At the same time, therapeutic interventions administered only during reperfusion reduce the extent of the tissue injury, thus implying better recovery of the limb ${ }^{19,20}$. In this sense, the success of some therapies employed indicates that even a late treatment administered at the end of ischemia and during reperfusion, can still be a determinant of a successful revascularization ${ }^{21}$.

The purpose of the composition of the solutions used to attenuate injuries resulting from reperfusion is to comply with the following principles: limit the calcium inflow, control hyperosmolarity, reduce the production of free radicals, increase glucose level e reverse tissue acidosis ${ }^{6}$.

The technique of controlled reperfusion of the extremities is based on the hypothesis that, by controlling the composition and the conditions of perfusion of the solution that first contacts the endothelium and the postischemic tissues, there is a reduction in the reperfusion injuries caused by free radicals, pro-inflammatory substances, toxic metabolites released during metabolic acidosis. Concerning this issue, there is an ample series of possibilities in terms of improving these solutions, if we consider the ischemia-reperfusion process a major inflammatory reaction. Up to this date there are neither effective treatments nor large, prospective, multicenter study with antioxidant drugs such as alpha-tocopherol, which was used in this study. This fact has led to the use of associations of antioxidants and to a tendency towards a multifactorial approach, where the ischemia/reperfusion is considered a complex phenomenon.

This encourages us to do new research and emphasize the importance of researches on this theme with the purpose of promoting its application in the clinical practice by using antioxidant substances in experimental studies, thus obtaining a more effective treatment for the metabolic changes secondary to ischemia/reperfusion and, therefore, reducing the incidence of amputations and deaths in these patients.

\section{Conclusion}

From the serum biochemical perspective, alphatocopherol attenuated metabolic injuries in the ischemia/ reperfusion syndrome in rats.

\section{References}

1. Harman JW. The significance of local vascular phenomena in the production of ischemic necrosis in skeletal muscle. Am J Pathol. 1948;24:625-44.

2. McCord JM. Oxygen-derived free radicals in postischemic tissue injury. N Engl J Med. 1985;312:159-63.

3. Korthuis RJ, Granger DN, Townsley MI, Tayler AE. The role oxygen - derived free radicals in ischemic-induced increases in canine skeletal muscle vascular permeability. Circ Res. 1985;57:599-609.

4. Walker PM, Lindsay TF, Labbe R, Mickle DA, Romaschin AD. Salvage of skeletal muscle with free radical scavengers. J Vasc Surg. 1987;5:68-75.

5. Smith JK, Carden DL, Grisham MB, Granger DN, Korthuis RJ. Role of iron in post ischemic microvascular injury. Am J Physiol. 1989;256(5 Pt 2):H1472-7.

6. Bozkurt AK. Alpha-tocopherol (Vitamin E) and iloprost attenuate reperfusion injury in skeletal muscle ischemia/ reperfusion injury. J Cardiovasc Surg. 2002;43:693-6.

7. Lehr HA, Messmer K. Rationale for the use of antioxidant vitamins in clinical organ transplantation. Transplantation. 1996;62:1197-9.

8. Nagel E, Meyer zu Vilsendorf A, Bartels M, Pichlmayr R. Antioxidative vitamins in prevention of ischemia/ reperfusion injury. Int J Vitam Nutr Res. 1997;67:298-306.

9. Bitu-Moreno J, Beyersdorf S, Schlensak C, Francischetti I, Dern P, Doenst T. Reperfusão controlada de membros inferiores com um sistema simplificado de perfusão. Rev Angiol Cir Vasc. 2002,11:23-9.

10. Sokol RJ, McKim JM, Goff MC, Ruyle SZ, Devereaux MW, Han D, et al. Vitamin E reduces oxidant injury to mitochondria and the hepatotoxicity of taurochenodeoxycholic acid in the rat. Gastroenterology. 1998;114:164-74.

11. Siegel S, Castellan Jr NJ. Nonparametric statistics. 2ed. New York: McGraw Hill; 1988.

12. Hebel R, Stromberg MW. The circulation system. In: Hebel R, Stromberg MW. Anatomy of the laboratory rat. Baltimore: Williams \& Wilkins; 1976. p.91.

13. Souza Moraes MR, David Filho R, Baptista Silva JC, Ullian M, Franco MF, Gabriel A, et al. Effect of antibodies to intercellular adhesion molecule type 1 on the protection of distant organs during reperfusion syndrome in rats. Braz J Med Biol Res. 2003;36:605-12.

14. Sardinha WE. Isquemia e reperfusão na musculatura esquelética em ratos. Inibição das lesões lipoperoxidativas mediadas por radicais livres pela deferoxamina [Tese]. 
Universidade Federal de São Paulo; 1994.

15. Pery MO, Fantini G. Ischemia: profile of an enemy. Reperfusion injury of skeletal muscle. J Vasc Surg. 1987;6:231-4.

16. Francischetti I, Maffei FHA, Bitu Moreno J, Fuhrmann Neto M, Coelho MPV, Kai FHT, et al. Ação do ácido trissódio-cálcio-dietileno-triaminopentaacético (CaNa3DTPA) nas lesões de isquemia-reperfusão em membro posterior de rato. Acta Cir Bras. 2002;17:332-41.

17. Avunduk M, Yurdakul T, Erdemli E, Yavuz A. Prevention of renal damage by alpha tocopherol in ischemia and reperfusion models of rats. Urol Res 2003.;31:280-5.

18. Novelli GP, Adembri C, Gandini E, Orlandini SZ, Papucci L, Formigli L, et al. Vitamin E protects human skeletal muscle from damage during surgical ischemiareperfusion. Am J Surg. 1997;173:206-9.

19. Beyersdorf F, Matheis G, Krüger S, Hanselmann A, Freisleben HG, Zimmer G, et al. Avoiding reperfusion injury after limb revascularization: experimental observations and recommendations for clinical application. J Vasc Surg. 1989;9:757-66.

20. Schlensak C, Doenst T, Bitu Moreno J, Beyersdorf F. Controlled limb reperfusion with a simplified perfusion system. Thorac Cardiovasc Surg. 2000;48:274-8.

21. Vogt PR, Von Segesser LK, Pagotto E, Lijovic T, Turina MI. Simplified, controlled limb reperfusion and simultaneous revascularization for acute aortic occlusion. J Vasc Surg. 1996;23:730-3.

\section{Correspondence:}

Marcelo Gomes da Silva

Rua Candido Portinari, 53

40140-440 Salvador - BA Brazil

marcelogms@terra.com.br
Conflict of interest: none Financial source: none

Received: April 28, 2005

Review: May 23, 2005

Accepted: June 27, 2005

\section{How to cite this article:}

Silva MG, Castro AA, Ramos EAG, Peixoto E, Miranda Jr F, Pitta GBB, Costa RFB, Juliano Y. Histological and biochemical serum effects of alpha-tocopherol on ischemia/reperfusion-related injuries induced in the pelvic limb of rats. Acta Cir Bras. [serial on the Internet] 2005 Sept-Oct;20(5). Available from URL: $\underline{\text { http://www.scielo.br/acb }}$

\section{*Color figures available from http://www.scielo.br/acb}

\section{AVISO AOS AUTORES}

Solicita-se aos autores observarem o estilo e as normas da Revista Acta Cirúrgica Brasielira.

Consultar os artigos publicados em fascículos recentes da revista.

Acessar http://www.scielo.br/acb - Instruções aos autores.

Informações adicionais pelo e-mail: sgolden@terra.com.br

VISITE O NOSSO SITE

SOCIEDADE BRASILEIRAPARA O

DESENVOLVIMENTO DA PESQUISAEM CIRURGIA

SOBRADPEC

http://www.sobradpec.org.br 